\title{
EVALUATION OF THE RESERVED ENERGY RESOURCES FOR NIGERIA POWER GENERATION AND TRANSMISSION CAPACITIES IMPROVEMENT
}

\author{
I. O. Akwukwaegbu ${ }^{1}$, E. N. C. Okafor ${ }^{2}$, F. I. Izuegbunam $^{3}$, M. C. Ndinechi ${ }^{4}$ \\ ${ }^{1,2,3,4}$ Department of Electrical and Electronic Engineering, Federal University of Technology, Owerri, Nigeria. \\ isdoreonyema@gmail.com
}

\begin{abstract}
The problem of inadequate electric power generation has contributed to slow pace of industrialization of Nigeria. The present poor energy mix as well as lack of development of the abundant energy resources has made electric power a scarce commodity in our country, affecting virtually every aspect of our economy. An introduction of reserved energy resources of coal, natural gas and new hydro potentials to the existing generation mix will definitely pave way for industrialization of the country. The erratic and epileptic state of power supply in Nigeria resulting to insufficient generation to meet the load demand would be solved by harnessing the abundant reserved energy potentials of our nation. This paper thus presents the reserved energy resources to electric power potential conversion algorithm, and incorporated the converted power into the existing installed power generation capacity for a new improved generation capacity. New transmission lines were equally introduced to the present grid system for efficient power wheeling capability. The reserved estimated energy resources of coal, natural gas and new hydro potentials were evaluated to contribute a total of 63,876.96MW to the grid system; and when added to the existing installed capacity of $12,066 \mathrm{MW}$ will give a total of 75,942.96MW.
\end{abstract}

Keywords: Reserved Energy Resources, Electric Power Potential, Estimated Reserve, Proven Reserve, Coal, Natural Gas, Hydro Potential

\section{INTRODUCTION}

The electric power system of a country must meet the electricity demand of the citizens. Every household and business office should have access to adequate power supply.

Energy is a means of satisfying important needs of a society. The industrial growth rate of Nigeria is a function of the amount of reserved energy resource available and the extent to which this reserved energy resource is utilized for the design and the construction of additional power plants in sufficient numbers. Nigeria has sufficient reserved energy resources of coal, natural gas and new discovered hydro potentials that can serve as an input to all economic activities. Reserved energy resources of coal, natural gas and new discovered hydro potentials are the energy producing installations basket that contains power plants fired by fossil fuels (coal and natural gas) and hydro potentials. The proven reserved coal in Nigeria is about 445 million tones, consisting approximately of $81.05 \%$ sub-bituminous, $4.81 \%$ bituminous and $14.14 \%$ lignite coals. The estimated reserved coal in Nigeria is about 2,559 million tones, consisting approximately of $42.32 \%$ sub-bituminous, $45.17 \%$ bituminous and $12.51 \%$ lignite coals. The reserved proven coal and estimated coal can contribute 1,964MW and $12,082 \mathrm{MW}$ respectively to the grid system at $60 \%$ capacity utilization for over 100 years. The total reserved proven natural gas in Nigeria are 4 trillion cubic meters (or 142 trillion standard cubic feet) and 5.4 trillion cubic meters (or 189 trillion standard feet) respectively. The reserved proven natural gas and estimated natural gas can contribute $29,505 \mathrm{MW}$ and $39,270 \mathrm{MW}$ respectively to the grid system at a capacity of $60 \%$ for 100 years. The new discovered hydro potentials and the existing electricity generation capacity in Nigeria are about $12,525 \mathrm{MW}$ and $12,066 \mathrm{MW}$ respectively. The reserved estimated energy resources of coal, natural gas and new hydro potentials can contribute a total of $63,876.96 \mathrm{MW}$ to the grid system, and when added to the existing installed capacity of $12,066 \mathrm{MW}$ will give a total of $75,942.96 \mathrm{MW}$. Only $56.6 \% \quad(42,943.6 \mathrm{MW})$ of $75,942.96 \mathrm{MW}$ is utilized in the current generation and transmission capacities expansion that gives expanded 86bus network with the reserved energy resources.

The key factor in the Nigeria energy crises is the very wide gap between the demand of electricity and the available supply in the country $[1,2,3]$.

The Nigeria power system is currently suffering from inadequate generation and transmission capacity. The demand is much higher than the generation and this has led to constant load shedding and erratic power supply. The installed generation capacity of the Nigeria power system is currently $12,066 \mathrm{MW}$ with on-going included of which $18 \%$ is hydro, $10 \%$ is coal-fired thermal plants and $70 \%$ is gasfired thermal plants.

At present, only about $4,200 \mathrm{MW}$ is generated on the average compared to the installed capacity. Rural electrification schemes and connection of more consumers to the grid are expected, and the estimated power demand in Nigeria is $15,730 \mathrm{MW}[1,4]$. To meet this growing demand, energy resources models are formulated and deployed in the conversion of reserved energy resources of coal, natural gas and new hydro potentials into its equivalent electric power resource. The reserved-based electric power resource is incorporated into the existing installed power generation 
capacity for upgrading to higher generating capacity standard.

The existing transmission system is not sufficient to transfer the additional power injected to the grid by the new power plants from the reserved generation mix. New transmission lines are created and incorporated into the present grid system for efficient evacuation of the new expanded generated power capacity.

\section{STATUS OF THE RESERVED ENERGY}

\section{RESOURCES}

Generation capability can be achieved with large reserved of coal deposits, unlimited reserved quantity of gas and crude oil and abundant hydro reserve.

\subsection{Coal Fuel Resources}

Coal is a fossil fuel which is a natural substance, and is one of the world's most important sources of energy that is used to generate around $37 \%$ of electricity worldwide [5].

\subsection{Hydropower Reserved Resources}

Nigeria has abundant and undeveloped hydropower resources. Hydropower resources are classified as large, medium, intermediate, small, mini and micro scales. Large scale hydropower is defined internationally as any hydro installation rated at greater than 100MW. Medium scale hydropower is any hydro installation rated at the range 50 to $100 \mathrm{MW}$, whereas intermediate scale hydropower is any hydro installation rated at the range $10-50 \mathrm{MW}$; while small hydropower is defined internationally as any hydro installation rated at less than 10MW. Hydropower accounts for over $22 \%$ of the total power generation in Nigeria. The existing large scale hydropower generating plants in Nigeria are the $760 \mathrm{MW}$ capacity Kainji Dam, 578MW capacity Jebba Dam and 600MW capacity Shiroro Dam, all located in Niger State. Nigeria has large undeveloped hydropower potentials, some of which have been shown to be technically and economically viable.

\section{PRESENT POWER GENERATION CAPACITY}

Presently, the total installed power generating capacity in Nigeria is $12,066 \mathrm{MW}$, whilst the available capacity fluctuates between $3000 \mathrm{MW}$ and a little above 4000MW. Table 1 shows the installed capacity of the power plants and the current actual generation in Nigeria; while Table 2 shows the power plants under construction expected to be connected to the grid between 2012 and 2020.

Table 1: Power Generation capacity of the current Nigerian grid.

\begin{tabular}{|l|l|l|l|l|l|}
\hline S/N & Station & State & Turbine & Installed Capacity (MW) & Available Capacity (MW) \\
\hline 1 & Kanji & Niger & Hydro & 760 & 253 \\
\hline 2 & Jebba & Niger & Hydro & 578 & 351 \\
\hline 3 & Shiroro & Niger & Hydro & 600 & 402 \\
\hline 4 & Egbin & Lagos & Steam & 1320 & 900 \\
\hline 5 & Trans-Amadi & Rivers & Gas & 100 & 57.30 \\
\hline 6 & A. E. S. & Lagos & Gas & 302 & 211.80 \\
\hline 7 & Sapele & Delta & Steam & 1020 & 170 \\
\hline 8 & Ibom & Akwa-Ibom & Gas & 155 & 25.30 \\
\hline 9 & Okpai (Agip) & Delta & Gas & 480 & 221 \\
\hline 10 & Afam I - V & Rivers & Gas & 726 & 60 \\
\hline 11 & Afam VI (shell) & Rivers & Gas & 650 & 510 \\
\hline 12 & Delta & Delta & Gas & 900 & 281 \\
\hline 13 & Geregu & Kogi & Gas & 414 & 120 \\
\hline 14 & Omoku & Rivers & Gas & 150 & 53 \\
\hline 15 & Omotosho & Ondo & Gas & 335 & 88.30 \\
\hline 16 & Olorunshogbo Phase I & Ogun & Gas & 135 & 54.30 \\
\hline 17 & Olorunshogbo Phase II & Ogun & Gas & 200 & 105.50 \\
\hline & Total Power $\left(\mathbf{P}_{1}\right)$ & & & $\mathbf{8 8 2 5 M W}$ & $\mathbf{3 8 6 3 . 5 0 M W}$ \\
\hline
\end{tabular}

Table 2: Generation capacity of ongoing New plants.

\begin{tabular}{|l|l|l|l|}
\hline Station & State & Turbine & Installed capacity, MW \\
\hline Calabar & Cross River & Gas & 563 \\
\hline Egbema & Imo & Gas & 338 \\
\hline Ihorbor & Edo & Gas & 451 \\
\hline Gbarian & Bayelsa & Gas & 225 \\
\hline Alaoji & Abia & Hydro & 714 \\
\hline Eket & Cross River & Gas & 500 \\
\hline Obite & & Gas & 450 \\
\hline Total $\left(\mathbf{P}_{\mathbf{2}}\right)$ & & & $\mathbf{3 , 2 4 1}$ \\
& & & MW \\
\hline Grand Total $\left(\mathbf{P}_{\mathbf{1}}+\mathbf{P}_{\mathbf{2}}\right)$ & & $\mathbf{1 2 , 0 6 6} \mathbf{M W}$ \\
\hline
\end{tabular}


The installed capacities of existing and ongoing Nigeria power plants are estimated at $12,066 \mathrm{MW}$. This means that even with new plants and transmission lines being added, there may still be inefficient generation and transmission capacities due to demand increase.

\section{MATERIALS AND METHODS}

In this paper, the procedures taken for the conversion of reserved energy resources into its equivalent electric power resource include: development and formulation of energy reserved models; simulation of the energy reserved models to convert the reserved energy resources into its equivalent electric power; evaluation of the reserved - based electric power resource and incorporation of the reserved - based electric power resource into the existing installed power generating capacity.

\subsection{Conversion of Raw Coal Resources into}

\section{Electrical Energy}

Coal is burnt in power stations to generate electricity. Generally, the raw coal is first grounded into a powder which allows it to burn more quickly. The powdered coal is burnt at a high temperature of around 1,100 degrees Celsius. The heat energy is converted into steam energy $[5,6]$.

The high-pressure steam is passed into the turbine connected to a generator, which in turn is connected to the electricity grid.

When the steam is passed into the turbine, it causes the turbine shaft to rotate at high speeds (the speed is usually fixed at 3,000 rotations per minutes). This energy is converted into electricity by the generator and passed into the electricity grid $[7,8,9,10$,$] .$

Available data from Nigeria energy commission on the proven and estimated coal reserves in the various parts of the country are as shown in table 3 . Table 4 shows the heat content of various coal types.

Table 3: Composite of reserved proven and estimated coals.

\begin{tabular}{|l|l|l|l|l|l|}
\hline S/N & Coal type & $\begin{array}{l}\text { Proven reserves } \\
\text { (tons) }\end{array}$ & $\begin{array}{l}\text { Estimated reserves } \\
\text { (tons) }\end{array}$ & $\begin{array}{l}\text { \% proven } \\
\text { reserves }\end{array}$ & $\begin{array}{l}\% \text { estimated } \\
\text { reserves }\end{array}$ \\
\hline 1 & Sub-bituminous & $361 \mathrm{E}+06$ & $1083 \mathrm{E}+06$ & 81.05 & 42.32 \\
\hline 2 & Bituminous & $21.42 \mathrm{E}+06$ & $1156 \mathrm{E}+06$ & 4.81 & 45.17 \\
\hline 3 & Lignite & $63 \mathrm{E}+06$ & $320 \mathrm{E}+06$ & 14.14 & 12.51 \\
\hline & Total & $445.42 \mathrm{E}+06$ & $2559 \mathrm{E}+06$ & 100 & 100 \\
\hline
\end{tabular}

Table 4: Heat content of the coal reserves.

\begin{tabular}{|l|l|l|}
\hline s/n & Coal type & Heat content (GJ/ton) \\
\hline 1 & Bituminous & $27-30$ \\
\hline 2 & Sub - bituminous & $20-26$ \\
\hline 3 & Lignite & $10-19$ \\
\hline
\end{tabular}

Table 3 presents the composite of reserved proven and estimated coals in Nigeria. The proven coal reserve is about 445 million tones, consisting approximately of $81.05 \%$ subbituminous, $4.81 \%$ bituminous and $14.14 \%$ lignite coals, as shown in table 3 .

The estimated coal reserve of Nigeria is about 2,559 million tones, consisting approximately of $42.32 \%$ sub bituminous, $45.17 \%$ bituminous and $12.51 \%$ lignite coals, as presented in table 3 .

The conversion procedures of raw coal deposits in tones into their equivalent electrical energy in megawatt hour (MWH) for the proven and estimated coal reserves are detailed as follows:

I. The various raw coal reserves in different mines location of each state are aggregated by summing the various reserve quantities. The coal reserves from the various mines scattered in a particular state are pulled together to serve as fuel for a generation plant in the state. Column 1 of conversion results present only the states where the coal mines are located.

II. The type of raw coal deposited in each state is considered. This is important as it determines the heat or energy content of the raw coal reserves. Three raw coal types exist in Nigeria, namely bituminous, sub-bituminous and lignite. The heat content of the bituminous coal types ranges from 27 to $30 \mathrm{GJ} /$ ton. Sub-bituminous coal type has the heat content ranging from 20 to $26 \mathrm{GJ} /$ ton and that of lignite coal type ranging from 10 to $19 \mathrm{GJ} / \mathrm{ton}$. The heat content for variant coal types will serve as the conversion factors from tones to British Thermal Unit (BTU) as shown in table 4.

The three raw coal types are presented in column 2 of the conversion results.

III. The British Thermal Unit (BTU) is adopted as the unit of thermal energy. Column 3 of the conversion results has the raw coal reserves for the different states in tons. These raw coal reserves in tons are converted into their equivalent heat values in BTU as follows: 


\begin{tabular}{|c|c|c|}
\hline $\begin{array}{l}\mathrm{T}_{\mathrm{e}} \\
\text { type }\end{array}$ & $=$ & $\begin{array}{c}26.5 \times 10^{6} M \text { for bituminous coal } \\
\text { (1a) }\end{array}$ \\
\hline coal type & $=$ & $23 \times 10^{6} M$ for sub-bituminous \\
\hline & $=$ & $\begin{array}{c}14.5 \times 10^{6} M \text { for lignite coal type } \\
\text { (1c) }\end{array}$ \\
\hline
\end{tabular}

Where:

$\mathrm{T}_{\mathrm{e}} \quad$ = Thermal energy in BTU

$\mathrm{M} \quad$ = Mass of raw coal reserves in

tones

The computed thermal energy values in BTU are given in column 4 of the conversion results.

IV. The thermal energy content $\left(\mathrm{T}_{\mathrm{e}}\right)$ of the coal in BTU is converted into the equivalent electrical energy in watt-hour as follows:

$$
1 K W h=3412 \mathrm{BTU}
$$

Conversion ratio $=\mathrm{E}_{\mathrm{WH}}=\frac{1 K W h}{3412 B T U}$

$$
\begin{aligned}
& \frac{1 W h \times 10^{3}}{3412 B T U} \\
& 0.2931 \frac{W H}{B T U}
\end{aligned}
$$

Where:

$$
\mathrm{E}_{\mathrm{WH}}=
$$

The computed electrical energy values in $W H$ are given in column 4 of the conversion results.

V. The electrical energy content in $W H$ is further converted into the equivalent $60 \%$ conversion efficiency in $M W H$. The steam turbine is expected to work at $60 \%$ capacity utilization for 100 years. The electrical power in $M W$ is obtained as follows:

$$
\begin{aligned}
P & =\frac{E}{t}=\frac{E}{100 \text { years } \times 365 \times 24} \\
& =\frac{M W H}{87600 \text { Hours }}
\end{aligned}
$$

Where:

MWH

$$
\begin{array}{lll}
P & = & \text { Electrical power in MW } \\
E & = & \text { Electrical energy in } \\
t & = & \text { time in hours }
\end{array}
$$

The computed electrical power values in MW are presented in the last column of the conversion results. A MATLAB program was used to perform all the computations involving the conversion of raw coal reserves into electrical energy.

Figure 1 shows the algorithm (flow charts) of the conversion of raw coal reserves into electrical energy.

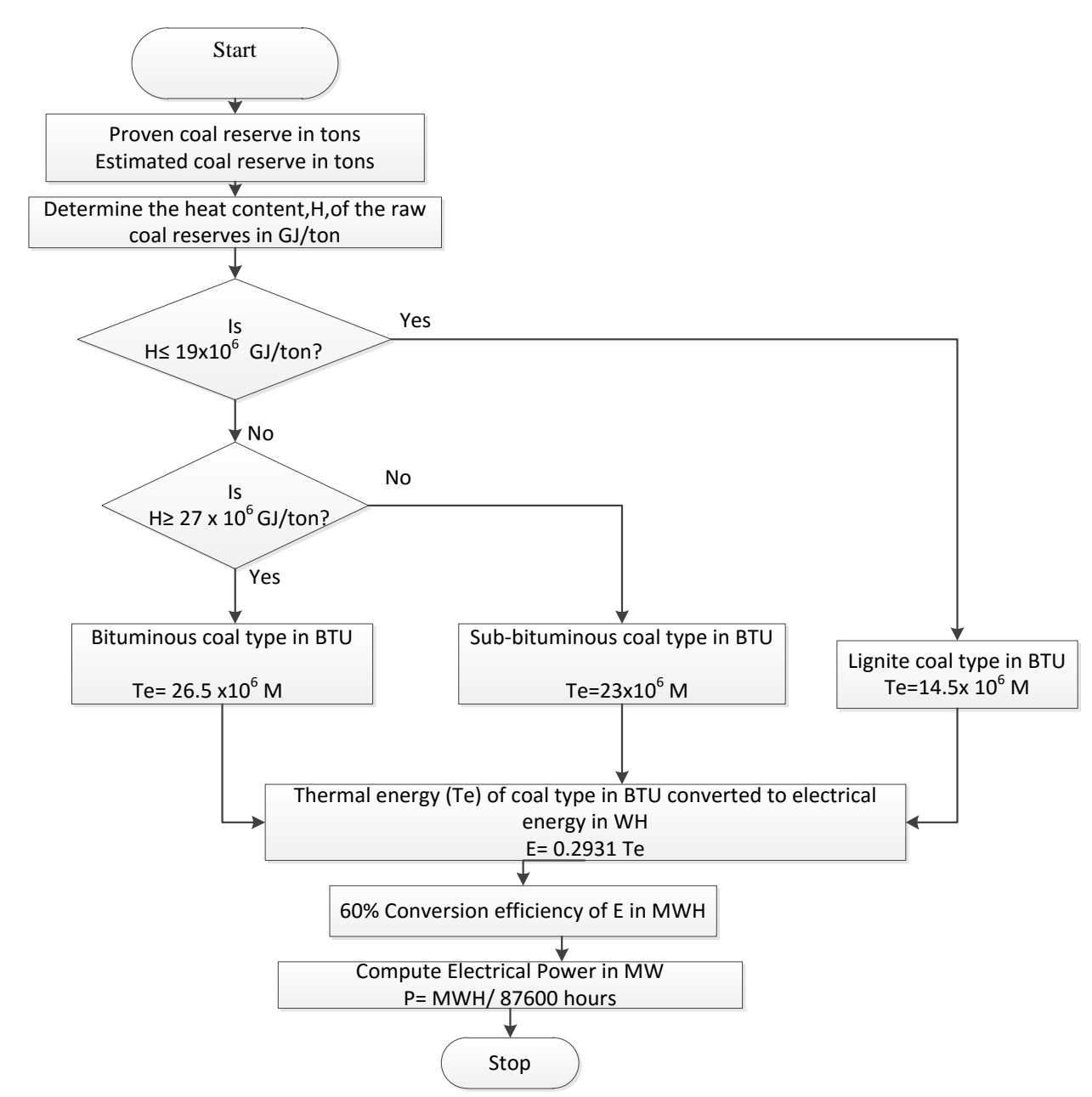

Fig. 1: Flow charts of the conversion of raw coal reserves into electrical energy. 
Table 5 shows the proven coal reserve in Nigeria and its electrical power potential.

Table 5: Proven Coal Reserve in Nigeria and the Computed Values of Electrical Power Potential.

\begin{tabular}{|c|c|c|c|c|c|c|c|c|}
\hline $\begin{array}{l}\mathbf{S} \\
/ \\
\mathbf{N} \\
\end{array}$ & State & Coal Type & $\begin{array}{l}\text { Proven } \\
\text { Reserve } \\
\text { (Tons) } \\
\end{array}$ & $\begin{array}{l}\text { Thermal Energy } \\
\text { (BTU) } \\
\text { (26.5E +6 for Bit) } \\
\text { (23E +6 for S/Bit) } \\
\text { (14.5E +6 for Lig) }\end{array}$ & $\begin{array}{l}\text { Electrical } \\
\text { Energy } \\
(\mathrm{WH}) \\
(\mathbf{0 . 2 9 3 1}) \\
\end{array}$ & $\operatorname{MWH}\left(/ \mathbf{1 0}^{6}\right)$ & $\begin{array}{l}\text { Eff }=60 \% \\
(\text { MWH 0.6) }\end{array}$ & $\begin{array}{l}\text { Electrical } \\
\text { Power } \\
\text { (MW) } \\
(/ 876000) \\
\end{array}$ \\
\hline 1 & Enugu & Sub-bituminous & $140 \mathrm{E}+06$ & $3.22 \mathrm{E}+15$ & $9.44 \mathrm{E}+14$ & $9.44 \mathrm{E}+08$ & $5.66 \mathrm{E}+08$ & 646.43 \\
\hline 4 & Nassarawa & Bituminous & $21.42 \mathrm{E}+06$ & $5.68 \mathrm{E}+14$ & $1.66 \mathrm{E}+14$ & $1.66 \mathrm{E}+08$ & $9.98 \mathrm{E}+07$ & 113.95 \\
\hline \multirow[t]{2}{*}{5} & Benue & Sub-bituminous & $57 \mathrm{E}+06$ & $1.31 \mathrm{E}+15$ & $3.84 \mathrm{E}+14$ & $3.84 \mathrm{E}+08$ & $2.31 \mathrm{E}+08$ & 263.19 \\
\hline & Total & & $445.42 \mathrm{E}+06$ & $9.782 \mathrm{E}+15$ & $2.872 \mathrm{E}+15$ & $2.872 \mathrm{E}+15$ & $2.872 \mathrm{E}+09$ & 1964.20 \\
\hline
\end{tabular}

From the results computed electric power values in mega watts of the proven coal reserves, it is found that Kogi State of Nigeria produced the highest proven coal reserve of 757.24MW, while the lowest proven coal reserve of 113.95MW was recorded by Nassarawa State of Nigeria.
The estimated coal reserves in million tones, occurred in various States of Nigeria and their computed equivalent values of electrical power in mega watts are as shown in table 6. From the results obtained, it is clear that Enugu State bituminous coal of Nigeria has the highest estimated coal reserve of 5,319.97MW, whereas the lowest estimated coal reserve of $87.33 \mathrm{MW}$ came from Anambra State.

Table 6: Estimated Coal Reserve in Nigeria and the Computed Values of Electrical Power Potential.

\begin{tabular}{|c|c|c|c|c|c|c|c|c|}
\hline $\mathbf{S} / \mathbf{N}$ & State & Coal Type & $\begin{array}{l}\text { Estimated } \\
\text { Reserve } \\
\text { (Tons) }\end{array}$ & $\begin{array}{c}\text { Thermal } \\
\text { Energy } \\
\text { (BTU) } \\
\text { (26.5E +6 for } \\
\text { Bit) } \\
\text { (23E +6 for } \\
\text { S/Bit) } \\
\text { (14.5E +6 for } \\
\text { Lig) } \\
\end{array}$ & $\begin{array}{l}\text { Electrical } \\
\text { Energy } \\
(\mathbf{W H}) \\
(\mathbf{0 . 2 9 3 1})\end{array}$ & $\begin{array}{l}\text { MWH } \\
\left(/ \mathbf{1 0}^{6}\right)\end{array}$ & $\begin{array}{l}\text { Eff }=60 \% \\
(M W H \\
0.6)\end{array}$ & $\begin{array}{l}\text { Electrical } \\
\text { Power } \\
(\mathrm{MW}) \\
(/ \mathbf{8 7 6 0 0 0 )}\end{array}$ \\
\hline 1 & Enugu & Bituminous & $1000 \mathrm{E}+06$ & $2.65 \mathrm{E}+06$ & $7.77 \mathrm{E}+15$ & $7.77 \mathrm{E}+09$ & $4.66 \mathrm{E}+09$ & 5319.97 \\
\hline 2 & Enugu & $\begin{array}{l}\text { Sub- } \\
\text { bituminous }\end{array}$ & $456 \mathrm{E}+06$ & $10488 \mathrm{E}+16$ & $3.074 \mathrm{E}+15$ & $3.074 \mathrm{E}+09$ & $1.84 \mathrm{E}+09$ & 2105.50 \\
\hline 3 & Imo & Lignite & $40 E+06$ & $5.80 \mathrm{E}+14$ & $1.70 \mathrm{E}+14$ & $1.70 \mathrm{E}+08$ & $1.02 \mathrm{E}+08$ & 116.44 \\
\hline 4 & Ebonyi & $\begin{array}{l}\text { Sub- } \\
\text { bituminous }\end{array}$ & $50 \mathrm{E}+06$ & $1.15 \mathrm{E}+15$ & $3.37 \mathrm{E}+14$ & $3.37 \mathrm{E}+08$ & $2.02 \mathrm{E}+08$ & 230.87 \\
\hline 5 & Anambra & Lignite & $30 \mathrm{E}+06$ & $4.35 \mathrm{E}+14$ & $1.28 \mathrm{E}+14$ & $1.28 \mathrm{E}+08$ & $7.65 \mathrm{E}+07$ & 87.33 \\
\hline 6 & Delta & Lignite & $250 \mathrm{E}+06$ & $3.63 \mathrm{E}+15$ & $1.062 \mathrm{E}+15$ & $1.062 \mathrm{E}+09$ & $6.36 \mathrm{E}+08$ & 727.73 \\
\hline 7 & Kogi & $\begin{array}{l}\text { Sub- } \\
\text { bituminous }\end{array}$ & $502 \mathrm{E}+06$ & $1.16 \mathrm{E}+16$ & $3.38 \mathrm{E}+15$ & $3.38 \mathrm{E}+09$ & $2.03 \mathrm{E}+09$ & 2317.90 \\
\hline 8 & Nassarawa & Bituminous & $156 \mathrm{E}+06$ & $4.13 \mathrm{E}+15$ & $1.21 \mathrm{E}+15$ & $1.21 \mathrm{E}+09$ & $7.27 \mathrm{E}+08$ & 829.92 \\
\hline 9 & Benue & $\begin{array}{l}\text { Sub- } \\
\text { bituminous }\end{array}$ & $75 E+06$ & $1.73 \mathrm{E}+15$ & $5.056 \mathrm{E}+14$ & $5.056 \mathrm{E}+09$ & $3.034 \mathrm{E}+08$ & 346.30 \\
\hline & Total & & $2559 \mathrm{E}+06$ & $1.049 \mathrm{E}+20$ & $1.76 \mathrm{E}+16$ & $1.76 \mathrm{E}+10$ & $1.058 \mathrm{E}+10$ & 12081.96 \\
\hline
\end{tabular}

\subsection{Conversion of Raw Natural Gas Reserves Into}

\section{Electrical Power}

A gas turbine plant consists of a compressor, combustion chamber, gas turbine and alternator. The compressor takes in atmospheric air, compresses it and supplies the pressurized air to the combustion chamber and burnt in the presence of air supplied by the compressor. The combustion raises the temperature of air and increases its volume under constant pressure. The products of combustion, after expansion through the turbine, are finally exhausted to the atmosphere [14]. 
The proven and estimated raw natural gas reserves in the various parts of the country are presented in tables 7 and 8 respectively. The computational procedures deployed in the conversion of raw coal reserves into electrical energy has been adopted in the conversion of raw natural gas reserves in trillion cubic meters (or trillion standard cubic feet) into electrical energy. The procedure includes:

(i) The conversion of raw natural gas reserves from cubic meters to cubic feet as follows:

1 cubic meter $=35.5$ cubic feet

$1 \mathrm{Q}_{\mathrm{CM}}=35.5 \mathrm{Q}_{\mathrm{CF}}$

Conversion ratio $=1 \mathrm{Q}_{\mathrm{CF}}=\frac{35.5 \mathrm{CF}}{1 Q_{C M}}$

4 trillion cubic meters $=4 \times 35.5$ trilion cubic feet

$$
\begin{aligned}
& =142 \text { trillion cubic feet } \\
& =142 \times 10^{12} \mathrm{Q}_{\mathrm{CF}}
\end{aligned}
$$

(ii) Conversion of the natural gas reserves from cubic feet to thermal energy in BTU as follows:

$1 \mathrm{Q}_{\mathrm{CF}}=1035 \mathrm{BTU}$

or, $1 Q_{\mathrm{BTU}}=\frac{1035 B T U}{1 Q_{C F}}$

$1 \mathrm{KWh}=3412 \mathrm{BTU}$

$$
E_{W H}=\frac{1 K W h}{3412 B T U}=\frac{1 W h \times 10^{3}}{3412 B T U}=0.2931 \frac{W H}{B T U}
$$

(6) Where

$\mathrm{Q}_{\mathrm{CM}}=\quad$ Quantity of natural gas in cubic meters

$\mathrm{Q}_{\mathrm{CF}}=$ Quantity of natural gas in cubic feet
$\mathrm{Q}_{\mathrm{BTU}}=$ Quantity of natural gas in BTU

Step 4 - 5 computational procedures for the conversion of raw coal reserves into electrical energy are adopted here.

The electrical energy content in WH is converted into the equivalent $60 \%$ conversion efficiency in MWH. The gas turbine is expected to work at $60 \%$ capacity utilization for 100 years. The electrical power in MW is computed as follows:

$$
P=\frac{E}{t}=\frac{E}{100 \text { years } \times 365 \times 24}=\frac{M W H}{87600 \text { Hours }}
$$

The computational software program used for converting the quantity of natural gas into megawatt is MATLAB.

Table 7 presents the proven natural gas reserves in trillion cubic meters ( or trillion standard cubic feet), occurring in various states of federation and their computed equivalent values of electrical power in megga watts. From table 7 , the total proven natural gas reserve in Nigeria is about 4 trillion cubic meters (or 142 trillion standard cubic feet). This proven natural gas reserves can support $29,505 \mathrm{MW}$ capacity power plants operating at a capacity factor of $60 \%$ for 100 years.

The computed equivalent electrical power values in megga watts from the proven natural gas reserves show that the maximum and minimum proven natural gas reserves could produce electrical power of 7,081MW (or 24\% ) and $885 \mathrm{MW}$ (or $3 \%$ ) from the reserves located in Rivers State and Imo or Abia States respectively.

\begin{tabular}{|c|c|c|c|c|c|c|c|c|c|}
\hline $\mathbf{S} / \mathbf{N}$ & State & $\begin{array}{c}\text { Proven Gas } \\
\text { Reserve in } \\
\text { trillion } \\
\text { cubic } \\
\text { meters } \\
\left(\times 10^{12}\right. \\
\text { cubic } \\
\text { meters }) \\
\end{array}$ & $\begin{array}{l}\text { Proven } \\
\text { Gas } \\
\text { Reserve } \\
(\%) \\
\end{array}$ & $\begin{array}{l}\text { Gas in cubic } \\
\text { feet ( } X 35.5 \\
\text { CF) }\end{array}$ & $\begin{array}{l}\text { Thermal } \\
\text { Energy } \\
\text { (BTU) (X } \\
\text { 1035) } \\
\end{array}$ & $\begin{array}{l}\text { Electrical } \\
\text { Energy } \\
(\mathrm{WH}) \\
(\times \mathbf{0 . 2 9 3 1})\end{array}$ & $\begin{array}{l}\text { MWH } \\
\left(/ \mathbf{1 0}^{6}\right) \\
\end{array}$ & $\begin{array}{l}\text { Eff }=60 \% \\
(M W H \quad X \\
0.6)\end{array}$ & $\begin{array}{l}\text { Electrical } \\
\text { Power } \\
(\mathrm{MW})(/ 876000)\end{array}$ \\
\hline 1 & Rivers & $0.96 \times 10^{12}$ & 24 & $3.408 \times 10^{13}$ & $3.527 \times 10^{16}$ & $1.034 \times 10^{16}$ & $1.034 \times 10^{10}$ & $6.203 \times 10^{9}$ & 7081 \\
\hline 2 & Bayelsa & $0.60 \times 10^{12}$ & 15 & $2.130 \times 10^{13}$ & $2.205 \times 10^{16}$ & $6.462 \times 10^{15}$ & $6.462 \times 10^{9}$ & $3.877 \times 10^{9}$ & 4426 \\
\hline 3 & $\begin{array}{l}\text { Akwa- } \\
\text { Ibom }\end{array}$ & $0.80 \times 10^{12}$ & 20 & $2.840 \times 10^{13}$ & $2.939 \times 10^{16}$ & $8.615 \times 10^{15}$ & $8.615 \times 10^{9}$ & $5.169 \times 10^{9}$ & 5901 \\
\hline 4 & Delta & $0.80 \times 10^{12}$ & 20 & $2.840 \times 10^{13}$ & $2.939 \times 10^{16}$ & $8.615 \times 10^{15}$ & $8.615 \times 10^{9}$ & $5.169 \times 10^{9}$ & 5901 \\
\hline 5 & Edo & $0.48 \times 10^{12}$ & 12 & $1.704 \times 10^{13}$ & $1.764 \times 10^{16}$ & $5.169 \times 10^{15}$ & $5.169 \times 10^{9}$ & $3.102 \times 10^{9}$ & 354 \\
\hline 6 & Ondo & $0.16 \times 10^{12}$ & 4 & $5.680 \times 10^{12}$ & $5.879 \times 10^{15}$ & $1.723 \times 10^{15}$ & $1.723 \times 10^{9}$ & $1.034 \times 10^{9}$ & 1180 \\
\hline 7 & Imo & $0.12 \times 10^{12}$ & 3 & $4.260 \times 10^{12}$ & $4.409 \times 10^{15}$ & $1.292 \times 10^{15}$ & $1.292 \times 10^{9}$ & $7.754 \times 10^{9}$ & 885 \\
\hline 8 & Abia & $0.12 \times 10^{12}$ & 3 & $4.260 \times 10^{12}$ & $4.409 \times 10^{15}$ & $1.292 \times 10^{15}$ & $1.292 \times 10^{9}$ & $7.754 \times 10^{9}$ & 885 \\
\hline & Total & $4 \times 10^{12}$ & 100 & $142 \times 10^{12}$ & $1.470 \times 10^{17}$ & $4.308 \times 10^{16}$ & $4.308 \times 10^{10}$ & $2.585 \times 10^{10}$ & 29505 \\
\hline
\end{tabular}

Table 7 shows the results of proven gas reserve and its electric power value

Table 7: Proven Gas Reserve in Nigeria and the Computed Values of Electrical Energy Potentials.

Table 8 shows the values of the estimated natural gas reserves in trillion cubic meters (or trillion standard cubic feet), occurring in various States of Nigeria and their computed equivalent values of electrical power in mega watts. From table 8 , the total estimated natural gas reserve in Nigeria is about 5.4 trillion cubic meters (or 189 trillion 
standard cubic feet). This estimated natural gas reserve can support $39,270 \mathrm{MW}$ capacity power plants operating at a capacity factor of $60 \%$ for 100 years.

The computed equivalent electrical power values in mega watts from the estimated natural gas reserves show that
Rivers state of Nigeria has the highest estimated natural gas reserve capable of producing 9,425MW, while Imo or Abia State has the lowest estimated natural gas reserve that could give $1,178 \mathrm{MW}$.

Table 8: Estimated Gas Reserve in Nigeria and the Computed Values of Electrical Energy Potentials.

\begin{tabular}{|c|c|c|c|c|c|c|c|c|c|}
\hline $\mathrm{S} / \mathbf{N}$ & State & $\begin{array}{l}\text { Estimated } \\
\text { Gas Reserves } \\
\text { in trillion } \\
\text { cubic meters } \\
\left(\times 10^{12} \text { cubic }\right. \\
\text { meters })\end{array}$ & $\begin{array}{l}\text { Estimated } \\
\text { Gas } \\
\text { Reserves } \\
(\%) \\
\end{array}$ & $\begin{array}{llr}\text { Gas in cubic } \\
\text { feet }(X) & 35.5 \\
\text { CF }) & & \\
\end{array}$ & $\begin{array}{l}\text { Thermal } \\
\text { Energy } \\
\text { (BTU) (X } \\
\text { 1035) }\end{array}$ & $\begin{array}{l}\text { Electrical } \\
\text { Energy } \\
(\mathrm{WH}) \\
(\times \mathbf{0 . 2 9 3 1}) \\
\end{array}$ & MWH $\left(/ 10^{6}\right)$ & $\begin{array}{l}\text { Eff }=60 \% \\
(M W H \quad X \\
0.6)\end{array}$ & $\begin{array}{l}\text { Electrical } \\
\text { Power } \\
(\mathrm{MW})(/ \mathbf{8 7 6 0 0 0})\end{array}$ \\
\hline 1 & Rivers & $1.278 \times 10^{12}$ & 24 & $4.536 \times 10^{13}$ & $4.695 \times 10^{16}$ & $1.376 \times 10^{16}$ & $1.376 \times 10^{10}$ & $8.256 \times 10^{9}$ & 9425 \\
\hline 2 & Bayelsa & $0.7986 \times 10^{12}$ & 15 & $2.835 \times 10^{13}$ & $2.934 \times 10^{16}$ & $8.600 \times 10^{15}$ & $8.600 \times 10^{9}$ & $5.160 \times 10^{9}$ & 5891 \\
\hline 3 & $\begin{array}{l}\text { Akwa- } \\
\text { Ibom }\end{array}$ & $1.0648 \times 10^{12}$ & 20 & $3.780 \times 10^{13}$ & $3.912 \times 10^{16}$ & $1.147 \times 10^{15}$ & $1.147 \times 10^{10}$ & $6.880 \times 10^{9}$ & 7854 \\
\hline 4 & Delta & $1.0648 \times 10^{12}$ & 20 & $3.780 \times 10^{13}$ & $3.912 \times 10^{16}$ & $1.147 \times 10^{15}$ & $1.147 \times 10^{10}$ & $6.880 \times 10^{9}$ & 7854 \\
\hline 5 & Edo & $0.6389 \times 10^{12}$ & 12 & $2.268 \times 10^{13}$ & $2.347 \times 10^{16}$ & $6.880 \times 10^{15}$ & $6.880 \times 10^{9}$ & $4.128 \times 10^{9}$ & 4712 \\
\hline 6 & Ondo & $0.2130 \times 10^{12}$ & 4 & $7.560 \times 10^{12}$ & $7.825 \times 10^{15}$ & $2.293 \times 10^{15}$ & $2.293 \times 10^{9}$ & $1.376 \times 10^{9}$ & 1571 \\
\hline 7 & Imo & $0.1597 \times 10^{12}$ & 3 & $5.670 \times 10^{12}$ & $5.868 \times 10^{15}$ & $1.720 \times 10^{15}$ & $1.720 \times 10^{9}$ & $1.032 \times 10^{9}$ & 1178 \\
\hline \multirow[t]{2}{*}{8} & Abia & $0.1597 \times 10^{12}$ & 3 & $4.260 \times 10^{12}$ & $5.868 \times 10^{15}$ & $1.720 \times 10^{15}$ & $1.720 \times 10^{9}$ & $1.032 \times 10^{9}$ & 1178 \\
\hline & Total & $5.3775 \times 10^{12}$ & 100 & $189 \times 10^{12}$ & $1.956 \times 10^{17}$ & $5.733 \times 10^{16}$ & $5.733 \times 10^{10}$ & $3.440 \times 10^{10}$ & 39270 \\
\hline
\end{tabular}

Tables 9 and 10 show the comparison of electricity generation by proven and estimated fuel reserves respectively, in Nigeria. The proven fuel reserves of coal, natural gas and new discovered hydro potentials are compared with the highest value of $29,505 \mathrm{MW}$ coming from the natural gas. The proven and estimated fuel reserves can provide a total of 43,994.20MW and 63,876.96MW respectively to the grid with the highest value of $39,270 \mathrm{MW}$ coming from the natural gas.

Table 9: Electricity Generation by proven Fuel Reserve in Nigeria.

\begin{tabular}{|l|l|l|l|}
\hline Electricity Resource Mix & Proven Fuel Reserve & Percentage & Computed Generation Capacity (MW) \\
\hline Coal & $445.42 \times 10^{6}$ Tons & 4.46 & 1964.20 \\
\hline Natural Gas & 4 TCM or $142 \times 10^{12} \mathrm{CF}$ & 67.07 & 29505 \\
\hline Large Hydro Potential & & 28.47 & 12525 \\
\hline Total & & 100.00 & $43,994.20$ \\
\hline
\end{tabular}

Table 10: Electricity Generation by estimated Fuel Reserve in Nigeria.

\begin{tabular}{|l|l|l|l|}
\hline Electricity Resource Mix & Estimated Fuel Reserve & Percentage & Computed Generation Capacity (MW) \\
\hline Coal & $2559 \times 10^{6}$ Tons & 18.91 & 12081.96 \\
\hline Natural Gas & $5.32 \mathrm{TCM}$ or $189 \times 10^{12} \mathrm{CF}$ & 61.48 & 39270 \\
\hline Large Hydro Potential & & 19.61 & 12525 \\
\hline Total & & 100.00 & 63876.96 \\
\hline
\end{tabular}


Table 11 shows the comparison of existing and on - going electricity generation by fuel, while Table 12 shows the comparison of electricity generation by proven fuel reserves, existing and on - going generation in Nigeria. The existing and on-going can provide a total of $12,066 \mathrm{MW}$ to the grid. While the proven fuel reserve, existing and on-going can provide a total of $56,060 \mathrm{MW}$ to the grid.

Table 11: Capacity realizable by existing and ongoing projects in Nigeria.

\begin{tabular}{|l|l|l|}
\hline Electricity Resource Mix & Percentage & Installed Generation Capacity (MW) \\
\hline Coal: Existing & 19.39 & 2340 \\
Ongoing & Nil & Nil \\
\hline Natural Gas: Existing & 37.68 & 4547 \\
Ongoing & 18.90 & 2280 \\
\hline Hydro: Existing & 16.06 & 1938 \\
Ongoing & 7.97 & 961 \\
\hline Total & 100 & 12066 \\
\hline
\end{tabular}

Table 12: Generation by Fuel Reserve, existing and Ongoing projects in Nigeria.

\begin{tabular}{|l|l|l|}
\hline Electricity Resource Mix & Percentage & Computed Generation Capacity (MW) \\
\hline Total Proven Reserve Capacity & 78.48 & $43,994.20$ \\
\hline Total Existing and Ongoing Electricity Generation Capacity & 21.52 & 12,066 \\
\hline Grand Total & 100.00 & $56,060.20$ \\
\hline
\end{tabular}

Table 13 shows the comparison of electricity generation by estimated fuel reserves and existing and on - going generation by fuel in Nigeria. This can contribute a total of $75,942.96 \mathrm{MW}$ to the grid system.

Table 13: Comparison of Electricity Generation by Estimated Fuel Reserve and Existing and Ongoing Generation by Fuel in Nigeria.

\begin{tabular}{|l|l|l|}
\hline Electricity Resource Mix & Percentage & Computed Generation Capacity (MW) \\
\hline Total Estimated Reserve Capacity & 84.11 & $63,876.96$ \\
\hline Total Existing and Ongoing Electricity Generation Capacity & 15.89 & 12,066 \\
\hline Grand Total & 100.00 & $75,942.96$ \\
\hline
\end{tabular}

\subsection{Evaluation and Integration of Reserved- Based}

\section{Electric Power Resource and Existing Installed}

\section{Capacity.}

The reserved estimated energy resources of coal, natural gas and new hydro potentials would contribute a total $63,876.96 \mathrm{MW}$ to the grid; and when added to the existing installed capacity of $12,066 \mathrm{MW}$ will give a total of $75,942.96 \mathrm{MW}$ as seen in table 13 . The new power stations of several megawatts from reserved energy resources of coal fired, gas fired and hydro power plants are created and added to the existing 28 - bus grid shown in fig. 2 resulting to an expanded network of 86-bus shown in fig.3, leading to an increase in the number generator buses from 10 to 51 , load buses from 18 to 35; generation capacity expanded from $12,066 \mathrm{MW}$ to $42,943.6 \mathrm{MW}$, while the transmission lines increased from $5,988 \mathrm{Km}$ to $11,711 \mathrm{Km}$. The number of single lines and double lines improved from 16 to 34 and 16 to 58 respectively. More loops were equally created in the network from 4 to 7 as can be seen in table 16 and fig. 3 respectively.
Thirteen (13) new coal-fired power plants with bus-bars coloured blue contributed $13,000 \mathrm{MW}$ to improve the existing 28 - bus test system. These new coal fired power plants are designated as Kwara, Ondo, Delta1, Kogi, Anambra, Bauchi, Gombe, Bukuru, Plateau1, Adamawa, Benue, Enugu and Ebonyi as shown in table 14.

Eight (8) new natural gas fired power plants with bus- bars coloured yellow contributed $8,000 \mathrm{MW}$ to improve the exixting 28 - bus test system. These new natural gas- fired power plants are designated as Bayelsa, Delta3, Edo, Imo, Abia, Rivers, Mabon and Ibom, as shown in table 15.

Thirteen (13) new hydro power plants with bus- bars coloured red contributed $12,153 \mathrm{MW}$ to improve the existing 28 - bus test system. These new hydro power plants are designated as Mambilla, Zungeru, Danko, Gurara, Sarkin, Lokoja, Obajana, Onitsha2, Plateau2, Kastina Ala1, Ikom, Kasimbila, Katsina Ala2.

Forty one (41) more generating units from the reserved energy resources added to existing power plants will result in increased power flow on transmission lines in the grid, as shown in expanded 86 - bus system with the reserved energy resources of fig. 3 . 
Table 14: proposed coal - fired power plants with the reserved energy resources.

\begin{tabular}{|l|l|l|l|l|l|}
\hline \multicolumn{9}{|l|}{ PROPOSED } & EXISTING & With black bus-bars & $\begin{array}{l}\text { Capacity } \\
\text { (MW) }\end{array}$ \\
\hline Bus No & With blue bus-bars & $\begin{array}{l}\text { Capacity } \\
(\mathrm{MW})\end{array}$ & Bus No & Sapele PS & 1020 \\
\hline 8 & Kwara & 1000 & 13 & & \\
\hline 11 & Ondo & 1000 & & & \\
\hline 14 & Delta1 & 1000 & & & \\
\hline 34 & Kogi & 1000 & & & \\
\hline 36 & Anambra & 1000 & & & \\
\hline 38 & Bauchi & 1000 & & & \\
\hline 39 & Gombe & 1000 & & & \\
\hline 40 & Bukuru & 1000 & & & \\
\hline 41 & Plateau 1 & 1000 & & & \\
\hline 42 & Adamawa & 1000 & & & \\
\hline 44 & Benue & 1000 & & & \\
\hline 50 & Enugu & 1000 & & & \\
\hline 51 & Ebonyi & 1000 & & & \\
\hline & Total & $\mathbf{1 3 , 0 0 0 M W}$ & & & \\
\cline { 2 - 6 } & Overall Total & $\mathbf{1 4 , 0 2 0 M W}$ & & & \\
\hline
\end{tabular}

Table 15: Proposed Natural gas - fired power plants with the reserved energy resources.

\begin{tabular}{|c|c|c|c|c|c|}
\hline \multicolumn{3}{|c|}{ PROPOSED } & \multicolumn{3}{|c|}{ EXISTING } \\
\hline Bus No & With yellow bus-bars & $\begin{array}{l}\text { Capacity } \\
\text { (MW) }\end{array}$ & Bus No & With black bus-bars & $\begin{array}{l}\text { Capacity } \\
\text { (MW) }\end{array}$ \\
\hline 18 & Bayelsa & 1000 & 2 & Egbin & 1,320 \\
\hline 19 & Delta 3 & 1000 & 7 & Geregu & 414 \\
\hline 21 & Edo & 1000 & 9 & Omotosho & 335 \\
\hline 24 & Imo & 1000 & 10 & Papalanto & 335 \\
\hline 26 & Aba & 1000 & 15 & Delta 2 PS & 912 \\
\hline 28 & Rivers & 1000 & 16 & Gbaran & 225 \\
\hline 30 & Mabon & 1000 & 17 & Rain/Ube & 225 \\
\hline \multirow[t]{6}{*}{47} & Ibom & 1000 & 20 & Egema & 338 \\
\hline & & & 22 & Omoku PS & 252 \\
\hline & & & 23 & Agip Okpai PS & 480 \\
\hline & & & 25 & Alaoji & 504 \\
\hline & & & 27 & Afam $(\mathrm{i}-\mathrm{v})$ & 931.6 \\
\hline & & & 46 & Calabar & 561 \\
\hline \multicolumn{2}{|l|}{ Total } & 8,000MW & & & 6,832.6MW \\
\hline \multicolumn{2}{|c|}{ Overall total } & \multicolumn{4}{|c|}{ 14,832.6MW } \\
\hline
\end{tabular}

Comparison of the existing and the expanded transmission grids is giving in table 16 .

Table 16: Comparison of the existing and expanded transmission grids.

\begin{tabular}{|l|c|c|}
\hline & $\begin{array}{c}\text { Existing 330KV } \\
\text { transmission grid }\end{array}$ & $\begin{array}{c}\text { Expanded 330KV } \\
\text { transmission grid }\end{array}$ \\
\hline Number of generators & 10 & 51 \\
\hline Number of load buses & 18 & 35 \\
\hline Number of buses & 28 & 86 \\
\hline Grid capacity & $12,066 \mathrm{MW}$ & $42,943.6 \mathrm{MW}$ \\
\hline Grid transmission lines & $5,988 \mathrm{~km}$ & $11,711 \mathrm{~km}$ \\
\hline Number of single lines & 16 & 34 \\
\hline Number of double lines & 16 & 58 \\
\hline Number of loops & 4 & 7 \\
\hline
\end{tabular}

The necessary conditions for the selection and placement of additional generating plants into the test grid network are enumerated as follows: (a) A maximum return must be obtained with a minimum expenditure over the working life of the power plant. 
(b) The operation of such power plants should be carried out in such a way as to provide cheap, reliable and continuous service to ever increasing population.

Figs. 2 and 3 show the existing 28-bus Power network and 86-bus reserved- energy based expanded network.

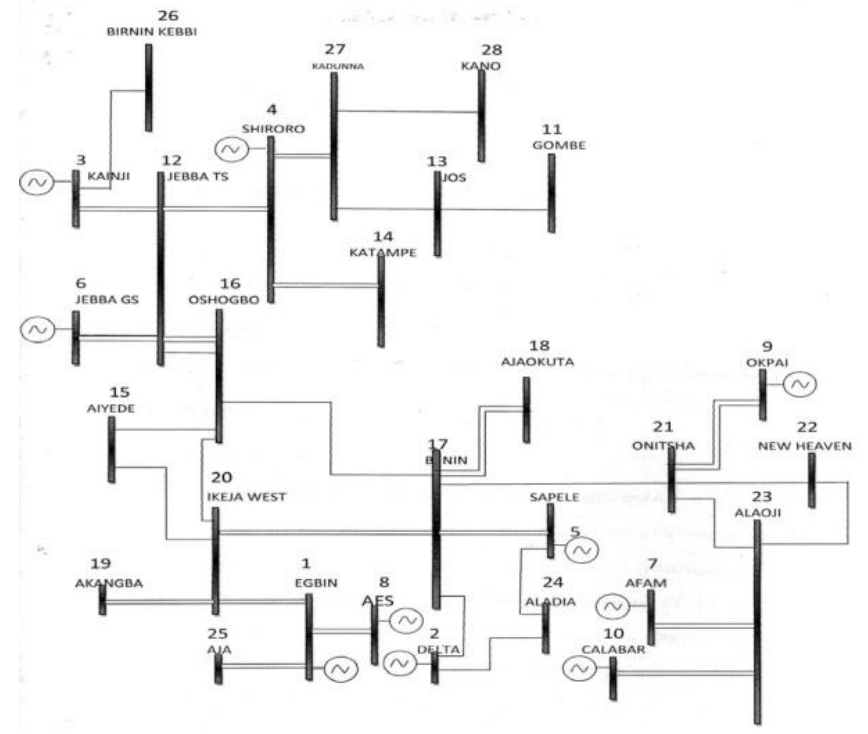

Fig. 2: The existing 28-bus 330KV Nigerian power grid

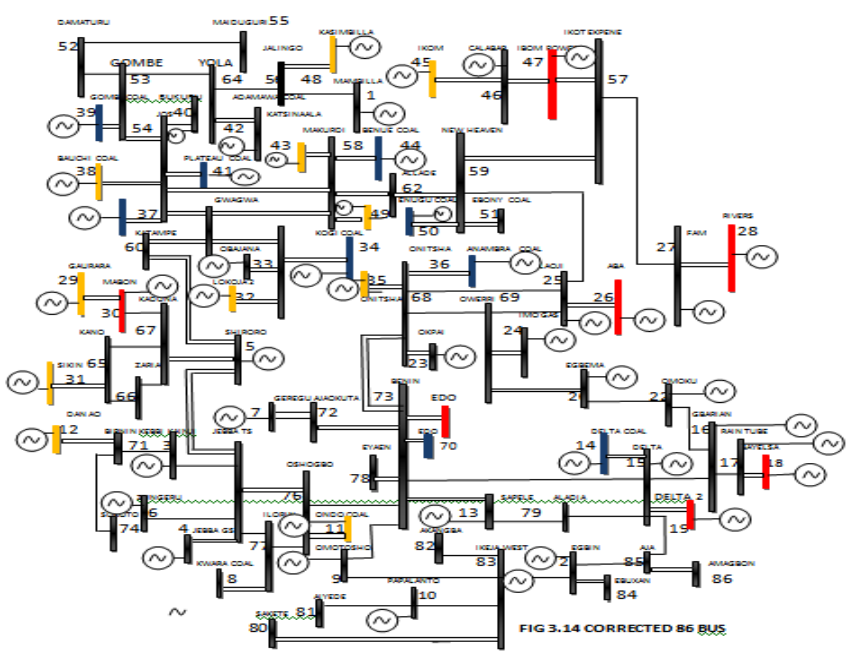

Fig 3: The expanded 86- bus power grid with reserved energy resources.

\section{CONCLUSION}

Effective sustainability, stability, efficiency and reliability of power supply based on increasing system loads would be achieved in Nigeria power system through the introduction of additional megawatts from abundant natural reserved energy resources. The reserved proven coal of 445 millions tons and estimated coal of 2,559million tons would contribute $1,964 \mathrm{MW}$ and $12,082 \mathrm{MW}$ respectively to the grid system at $60 \%$ capacity utilization for over 100 years.

The reserved proven natural gas of 4 trillion cubic meters (or 142 trillion standard cubic feet) and estimated natural gas of 5.4 trillion cubic meters (or 189 trillion standard cubic feet) would contribute $29,505 \mathrm{MW}$ and $39,270 \mathrm{MW}$ respectively to the grid system at capacity of $60 \%$ for 100 years.

The new discovered hydro potentials and the existing electricity generation capacity in Nigeria are $12,525 \mathrm{MW}$ and $12,066 \mathrm{MW}$ respectively. The reserved estimated energy resources of coal, natural gas and new hydro potentials would contribute a total of $63,876.96 \mathrm{MW}$ to the grid system, and when added to the existing installed capacity of $12,066 \mathrm{MW}$ will give a total of $75,942.96 \mathrm{MW}$. Only $56.6 \%$ $(42,943.6 \mathrm{MW})$ of $75,942.96 \mathrm{MW}$ is utilized in the current generation transmission capacities expansion that gives expanded 86-bus network.

\section{REFERENCES}

[1] Sambo, A.S., paper presented at the National Workshop on the Participation of State Government in the Power Sector: "matching supply with demand", Ladi Kwali Hall Sheraton Hotel and Towers ,Abuja, 29 July, 2008.

[2] Obadotil, D. J., Energy Crises in Nigeria Technical Issues and Solution, "Power sector prayer conference", June 25-37,2009.

[3] Akin Iwayemi, Nigeria's Dual Energy problems; Policy Issues and challenges, International Association for Energy Economics, 2010.

[4] Nigeria Vision 2020 Program, "Analysis for Power Generation capacity required to support 20; 2020 Economic vision"Report of the Energy Sector National Technical working Group.

[5] World Coal Association. http://www.coal.org.

[6] MMSD, Coal,Exploration and power Generating Opportunities in Nigeria, The Ministry of Mines and steel Development $\quad$ Nigeria, 2010. http//mmsd,gov.ng/Downloads/coal.pdf.

[7] Power Generation from Coal: Measuring and reporting Efficiency performance and $\mathrm{CO}_{2}$ Emission, International Energy Agency IEA Publications, October 2010.

[8] The mineral sector in Nigeria, http://www.maunfacturing.1odaynigeria.com/index.php/ analysis, $17^{\text {th }}$ Nigeria Economic summit, Wednesday 28 September, 2011.

[9] Energy Profile of Nigeria, http;//www. eoearth.org/ article/ energy.profile.of Nigeria published, October 11,2009. [10] Units and Conversion Facts sheet Derek supple, Massachusetts Institute of Technology. Energy club, http;//web.mit.edu/mit.energy.

[11] Energy Industry Conversion Factos, http;// www/platt.com/conversion tables.

[12] BLM:Utah: Electrical Conversion Calculations, USDepartment of the interior, http:// www.blm.gov/ut/st/en/prog/energy/coal/elecvtricity.convers ion.html.

[13] Energy Conversion in Nigeria-Hydro Potential of Nigeria, http:// www.gov.ng/index.

[14] Gupta, B. R., Generation of Electrical Energy, $1^{\text {st }}$ edu,S.Chand,Ram Nager,New Delhi, pp.109-127,2000. 